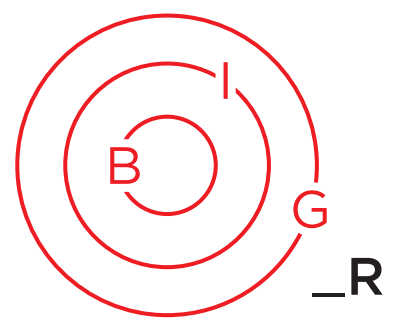

PORTFOLIO

PHOTOGRAPHY

\title{
Borderlanders of Lebanon: People from the In-between Spaces
}

\section{Daniel Meier and Hussein Baydoun}

This portfolio stems from a research project focusing on the many ways the residents of the border regions of Lebanon, or "borderlanders", live and perceive the international borders. Funded by the Heinrich Böll Stiftung (BerlinBeyrouth) and the Institut Convergences Migrations (Paris), this original research was conducted by photographer Hussein Baydoun and researcher Daniel Meier with the aim of visibalizing a category of unseen people: borderlanders. The men and women we met are privileged observers of the border and their lives shed a new light on it. Their daily experiences stand in stark contrast with most people's experience of borders, encountered only when travelling abroad. Borderlander perspectives can enrich our understanding of what a border is due to the deep meaning and impact it has on their lives.

This fieldwork, conducted in various locations in Lebanon, aims to understand what it means to live in a borderland region for each of the observers. Through their personal life experiences, they all brought to light how "their" border-the one they know and experience on a daily basis-provides them with opportunities and/or creates constraints. Each of them showed that a border is not an abstract phenomenon like a "line of sovereignty" but rather an entity that conditions their lives. In turn, all of them, Lebanese or refugees, underscored how they shape, use and transform this entity.
Our investigation shows that it is not sufficient to say that Lebanon has two very different border dyads - one with Syria and the other one with Israel. The country has far more borders because of the many and various relationships that exist along each segment of the international border, with their own local history and dynamics.

Among the borderland relationships, there is a specific one stemming from the presence of refugees: on the one hand, Syrians who fled the war and may expect to return home soon; on the other hand the Palestinians that appear far from any possible return to Palestine. Through years or decades, both are slowly becoming different from who they were before exile. Beyond the status of refugees or displaced persons, some of them developed a blurred or mixed identity, evidencing what borders can do to people's sense of self.

The portraits all define distinct relationships with the border. The border itself slowly appears as a dotted line which is fragmented, cut, sometimes isolated but also ideologized. The border is a location that reveals concerns, tensions and the stakes for local life. It is telling of identity and belonging. For these reasons, borders speak to all of us.

\section{Biographies}

Daniel Meier, Political Scientist, is Lecturer at the Global Studies Institute - University of Geneva, and associate researcher at the CNRS PACTE Grenoble. He also teaches regularly in Beirut, Venice and Turin. Member of the Association of Borderland Studies, his researches are focusing on borders and boundaries in the Middle East with a special dedication for interstitial spaces and people. His most recent edited book is titled In-Between Border Spaces in the Levant (Routledge 2021).

Email: Daniel.meier@graduateinstitute.ch Website: https://www.pacte-grenoble.fr/membres/daniel-meier

Hussein Baydoun is a Lebanese photojournalist with 14 years' experience and has worked for several local news websites and international agencies. He participated in exhibitions with ICRC, UNDP and the International festival "Visa pour l'image" as well as other projects. He is currently working as photojournalist at Al-Arabia al-Jadeed newspaper and website.

Email: husseinbaydoun.photography@gmail.com Instagram: husseinbaydoun.photography Twitter: @PhotographyHB 
He used to be called Abu Ahmad. He is 29 years old and a Syrian worker since a decade or more. Abu Ahmad used to work in Lebanon before the war in his country. We met him on the shores of the border river Nahr el-Kebir on the northern flank of Lebanon, riding his motorbike, registered in Syria. That day, he was discreetly helping another Syrian man to cross the river under the eyes of local inhabitants who came to fish.

Hamad Ribejih is in its 50s. He is a mason and lives in Abboudiyeh (North Lebanon) near the river Nahr el-Kebir for more than 30 years. At first sight, the place is a little strange, an abandoned village along a large road that abruptly stops at the river. He explains: "After the end of the war, I came here to take profit of the new project of the 'Arab Highway'. I decided to build a house and have a garage nearby but everything stopped with the assassination of former Prime Minister Rafic Hariri (in 2005)". Therefore, he retrained in the farm-tractor business with his cousin who was living in Syria and they undertook various trafficking across the border: "We used to smuggle a lot of things from Syria. Aside of Diesel petrol, tobacco, cleaning products, wheat, chickpeas, clothes, fabric, earthenware (for mural decoration). We also brought some stuff in Syria like porcelain and bananas. But since 2011, the border became a dangerous place."

Fouad is a wedding musician in his fifties. He lives in this Syrian refugee camp near Abboudiyeh (North Lebanon) with his wife. He warmly welcomed us in his tent to show us his musical ability but also to surprise us: "In fact, I am Lebanese" while showing us his ID card. "I used to live in a Syrian town not far from here until 2011. I met my wife there and we used to live there. Because of the war, I had to sell the lands and houses I possessed and move to Lebanon". He chose to live under a tent instead of buying a proper flat: "It was too expensive and moreover I had to choose between having a house and marrying my children...It's expensive to marry your children, you know?'

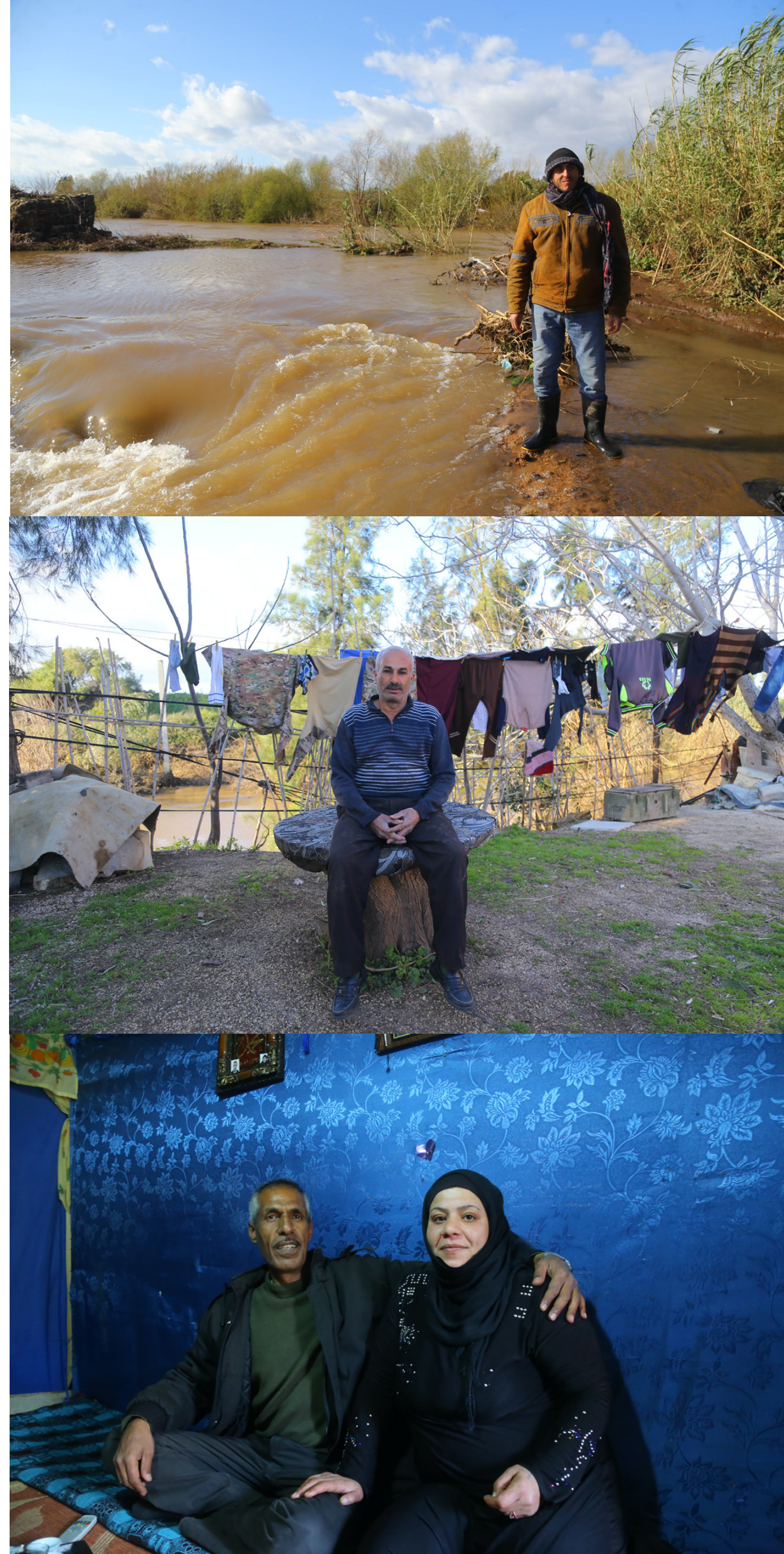




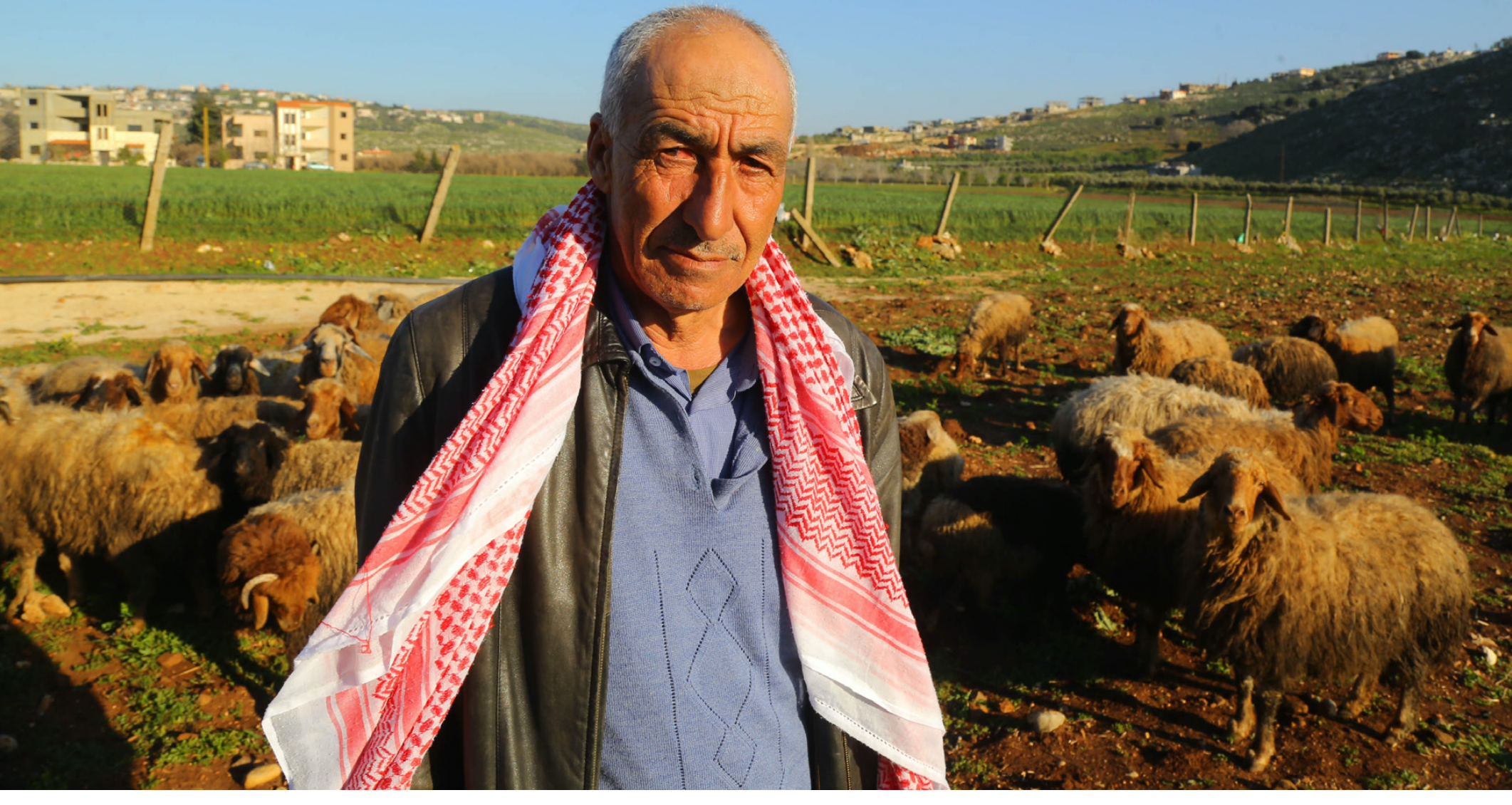


Borders in Globalization Review | Volume 2 | Issue 2 | Spring/Summer 2021 Meier and Baydoun, "Borderlanders of Lebanon: People from the In-between Spaces"

Ahmad Hussein Ezzeddine (previous page, top) is an energetic personage in his fifties. He is a shepherd from father to son in Wadi Khaled. "I was born here and I inherited this piece of land where we are standing. It goes up to the houses over there, near the border. Aside the flock, I also grow wheat, potatoes, corn and salads. Nothing is sent abroad, all the products stay here". For him, the border has a clear commercial function: "Before the war, we used to see Syrians coming here with goods that we were buying. But since then, it is over. Before, I used to go in Syria to find spare parts for my tractor; now it is not possible anymore and I found it annoying".

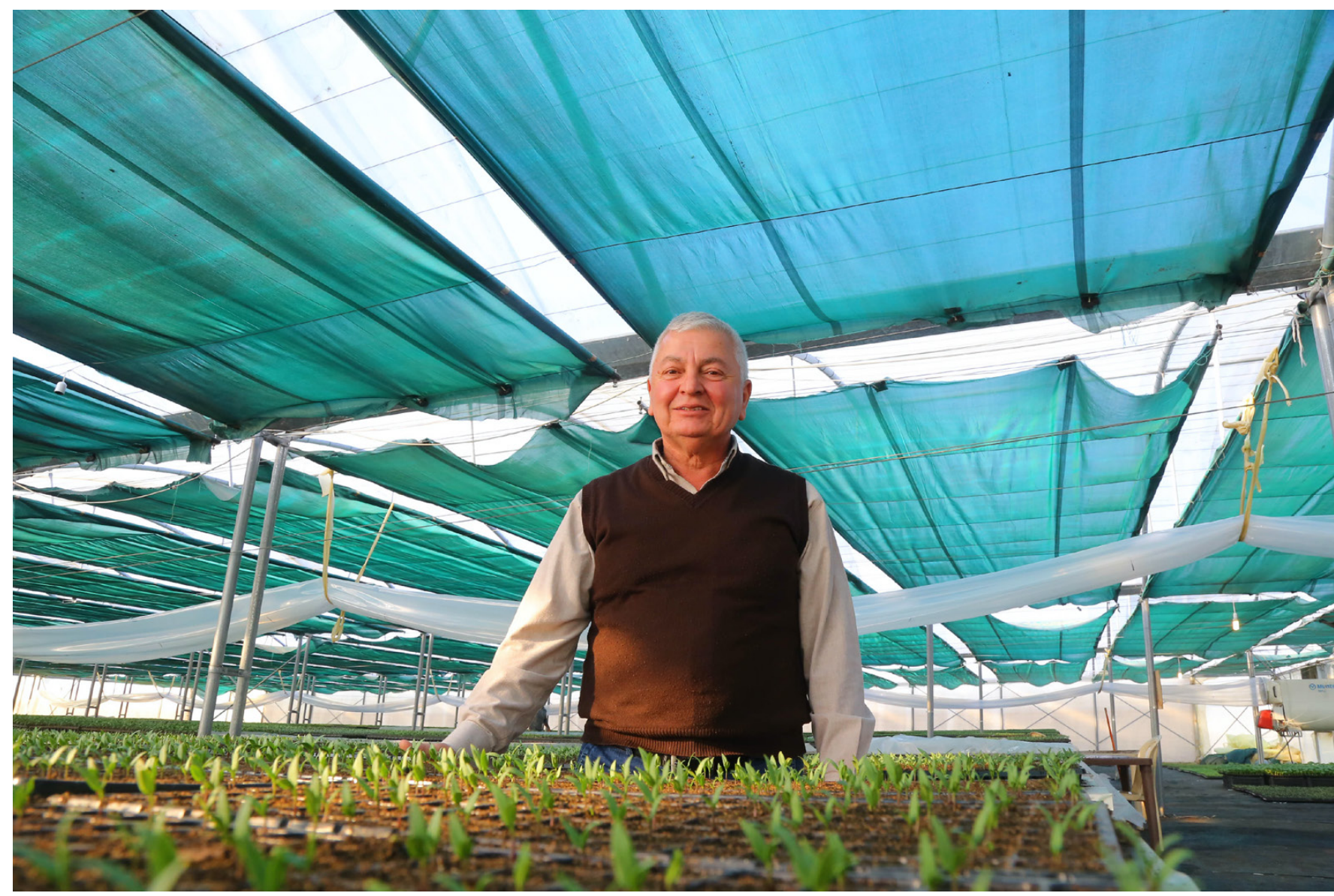

Naji Nasrallah, 61 years old, is from al-Qaa where he lives. He is a Christian businessman in agricultural products in Ras Baalbeck. Like his father, he is a farmer in this area, a region where he values the territorial depth on the Eastern flank. "We only once had a problem with Syrian soldiers because they were occupying our lands, it was in 1980. Before 2011, the border did not exist, Syrian policemen where on both sides of the border. Now, the Lebanese army took control of every inches of the national territory!' In 2017, the Lebanese army came back to these borderlands for the first time, once they were successful against the Jihadist in the Juroud of Arsal. "For the first time, our soldiers re-opened the border road, cleared the fields from any bombs and took control of the border. Without border, no country".

On the eastern flanks of the former no man's land (previous page, bottom), between the village of al-Qaa and the Syrian border post, 30,000 Syrian refugees sought refuge in the al-Qaa borderlands, most of them working in the fields of this fertile land. 
Mohammed Khaled Seeba, 56 years old, is a businessman in the construction field. He is a Syrian from Yabroud, a border town on the Syrian side of Anti-Liban mountains. "I left Yabroud in March 2014, the weather was cold. I left by car and I entered Lebanon illegally when the Lebanese Army arrested me and threw me in jail in Baalbeck. The general security freed me after paying 600 US\$. Then I came here to Arsal ... For me the border is a hajez (roadblock) between us and our neighbors. But to cross it and going back home to Syria, we demand international security to protect us". 
